\title{
Harmonisasi Hukum Pidana Adat Masyarakat Baduy dengan Hukum Pidana Nasional (RUU KUHP)
}

\author{
M. Noor Fajar Al Arif F \\ Fakultas Hukum Universitas Sultan Ageng Tirtayasa.e-mail: untirta_fajar@yahoo.co.id
}

\begin{abstract}
Customary law, especially customary criminal law must be used as a basic foundation in the formation of national criminal law. Because the customary criminal law contains values that can animate the national criminal law between the customary criminal law and still exists today, the Baduy customary criminal law. Although not all the same and there must be differences, efforts must be made to harmonize so that national criminal law and customary criminal law can complement each other. Therefore, customary criminal law holistically animates all layers of legal science in legal practice so that the existence of the legal science dimension is essentially Capability of customary criminal law is no doubt a characteristic of law in Indonesia.
\end{abstract}

Keywords: Harmonization; Baduy customary criminal law; Values

\section{PENDAHULUAN}

Pembangunan secara harfiah pada hakikatnya adalah suatu kegiatan yang bersifat mengubah keadaan dari yang lama menjadi baru, yang dilaksanakan secara bertahap. Oleh karena itu sasaran pembangunan adalah manusia Indonesia, maka perubahan yang diinginkan itu selain tertuju pada kebutuhan, juga akan mengubah sikap dan tingkah laku manusia itu sendiri. Oleh karena itu, pelaksanaan pembangunan perlu ditunjang oleh hukum sebagai pengarah dan sarana menuju masyarakat Pancasila. Sejalan dengan itu, dalam masa pembangunan ini, sebenarnya hukum tidak hanya diharapkan akan mampu berfungsi sebagai sarana pembaharuan masyarakat dan pengayom masyarakat, tetapi tampil di depan memberi arah pada pembentukan suatu masyarakat yang dicita-citakan. Oleh karena itu, yang perlu dilakukan adalah menata sistem hukum yang menyeluruh dan terpadu dengan mengakui dan menghormati hukum agama dan hukum adat serta memperbaharui perundang-undangan warisan kolonial dan hukum nasional yang bersifat diskriminatif termasuk ketidak adilan gender dan ketidak sesuaiannya dengan tuntutan reformasi melalui program reformasi program legislasi ${ }^{1}$.

Selanjutnya dapat dikemukakan di sini bahwa pembangunan pada hukum pidana, tidak semata hanya pada lingkup pembangunan bersifat struktural yaitu pada lembaga yang bergerak dalam prosedural tetapi juga pembangunan terhadap substansi atau produkproduk berupa peraturan hukum pidana dan yang bersifat kultural, yakni perilaku-

\footnotetext{
${ }^{1}$ Nyoman Serikat Putra Jaya (2016). Hukum (Sanksi) Pidana Adat Dalam Pembaharuan Hukum Pidana Nasional, Jurnal Masalah - Masalah Hukum, Jilid 45 No. 2, April 2016:123
} 
perilaku, nilai-nilai, asas-asas yang mempengaruhi berlakunya suatu sistem hukum. Usaha pembaruan hukum pidana sampai saat ini dilakukan dengan satu tujuan utama yakni menciptakan suatu kodivikasi hukum pidana materil untuk menggantikan kodivikasi hukum pidana warisan kolonial, yakni Wetboek van Starfrecht voor Nederlandsch Indie 1915 yang merupakan turunan dari Wetboek van Starfrecht negeri Belanda $^{2}$.

Sistem hukum di masyarakat hukum adat Baduy berbentuk tidak tertulis, namun hukum tersebut ditaati sebagai kumpulan norma-norma yang mencerminkan tingkah laku manusia dalam kehidupan kesehariannya dan ditaati karena mempunyai akibat hukum, bahkan menurut Soerojo Wignjodipoero ${ }^{3}$, hukum adat harus meninggalkan rasionalisme dan materialistis dan melihat dunia dengan riligius megis. J. H. P'Bellefroid, peraturan yang hidup meskipun tidak diundangkan oleh penguasa tetapi diyakini sebagai peraturan dan ditaati oleh rakyak $^{4}$, dari itu semua menimbulkan banyak pertanyaan tentang legalitas atau keabsahannya dalam pelaksanaan dan penegakkan hukumnya dan apakah bisa pemidanaan yang dijatuhkan mencapai sasaran seperti pada tujuan pemidanaan pada umumnya. Untuk menjawab pertanyaan itu maka kita tidak bisa melihat hukum dari sudut pandang secara umum tetapi harus melihat dari sudut pandang mereka.

Dikaji dari perspektif peraturan perundang-undangan Indonesia saat ini (ius constitutum) terminologi hukum adat dikaji dari perspektif asas, norma, teoretis dan praktik dikenal dengan istilah, "hukum yang hidup dalam masyarakat", "living law",

"nilai-nilai hukum dan rasa keadilan yang hidup dalam masyarakat", "hukum tidak tertulis", "hukum kebiasaan”, dan lain sebagainya.

Ruang lingkup kajian hukum adat diatur dalam beberapa instrument baik nasional maupun internasional, secara internasional Eksistensi berlakunya hukum adat selain dikenal dalam instrumen hukum nasional juga diatur instrumen Internasional. Ketentuan Pasal 15 ayat (2) International Covenant on Civil and Political Rights (ICCPR) menyebutkan bahwa, "Nothing in this article shall prejudice the trial and punishment of any person for any act or omission which, at the time when it was committed, was criminal according to the general principles of law recognized by the community of nations". Kemudian rekomendasi dari Konggres Perserikatan Bangsa-Bangsa (PBB) tentang "The Prevention of Crime and the Treatment of Offenders" dinyatakan bahwa sistem hukum pidana yang selama ini ada di beberapa Negara (terutama yang berasal/diimpor dari hukum asing semasa zaman kolonial), pada umumnya bersifat "obsolete and unjust" (telah usang dan tidak adil) serta "outmoded and unreal" (sudah ketinggalan zaman dan tidak sesuai dengan kenyataan). ${ }^{5}$

Ikhtiar untuk melakukan penggantian hukum pidana warisan kolonial menjadi hukum nasional (RUU KUHP) sudah dilakukan dan masih berlanjut sampai saat ini. Pembentukan hukum nasional tersebut dilakukan dengan hati-hati dank arena harus berdasarkan nilai-nilai atau jiwa bangsa Indonesia. Untuk mendapatkan bahan atau

\footnotetext{
${ }^{2}$ Ibid

${ }^{3}$ Soerojo Wignjodipoero (2017). Pengantar dan Asass Asas Hukum Adat, cetakan kedelapan, Jakarta: Gunung Agung. p. 43.

${ }^{4}$ C. Dewi Wulansari, (2014). Hukum Adat Indonesia Suatu Pengantar. Jakarta: Refika Aditama. p. 4.

${ }^{5}$ Lilik Mulyadi, EKSISTENSI HUKUM PIDANA ADAT DI INDONESIA : Pengkajian Asas, Norma, Teori, Praktik dan Prosedurnya, Jurnal Hukum dan Peradilan Volume 2 Nomor Juli 2013: 227.
} 
materi tersebut harus melakukan penggalian terhadap nilai-nilai hukum adat. Salah satu hukum adat yang menurut peneliti bagus untuk dikaji adalah hukum pidana adat masyarakat Baduy dengan titik fokus pada hukum pidana adat.

Pembentukan hukum pidana nasional pada hakikatnya adalah untuk memberikan kesejahteran kepada masyarakat, dalam pembentukan hukum tersebut harus dilakukan bijak dan dengan mengumpulkan berbagai sumber asli terutama hukum adat yang merupakan nilai-nilai dan jiwa bangsa salah satunya hukum adat masyarakat Baduy, walaupun pasti ada perbedaan maka harus dilakukan harmonisasi hukum pidana adat Baduy dengan hukum pidana nasional (RUU KUHP).

\section{METODE PENELITIAN}

Pendekatan penelitian dengan socio-legal-antro digunakan secara komprehensif untuk memperoleh, mengkaji dan menganalisis data primer dan data sekunder berupa perundang-undangan yang berkaitan dengan hukum adat Baduy. Mengingat penelitian ini menggunakan data primer dan data sekunder, maka pengumpulan data dilakukan dengan dua cara. Pertama, pengumpulan data sekunder dilakukan dengan cara studi kepustakaan dan studi dokumen yang berhubungan dan menunjang penelitian ini. Data sekunder yang dikumpulkan kemudian digunakan pada dua tahapan. Pertama dipelajari sebagai bahan pengetahuan awal peneliti sebelum melakukan field research ke Masyarakat Baduy. Kedua, pengumpulan data primer dilakukan dengan cara observasi (pengamatan) dan indepth intervie.

Metode analisis data yang dilakukan dalam penelitian ini adalah analisis kualitatif. Analisis kualitatif adalah analisis yang dilakukan dengan cara deskripsi analitis dari data primer dan sekunder yang telah diolah. Hasil analisa ini kemudian dilanjutkan dengan mengambil kesimpulan secara induktif, meneliti dari data dan fakta khusus untuk kemudian diambil kesimpulan-kesimpulan umum.

\section{ANALISIS}

Hukum adat lahir, tumbuh dan berkembang sekaligus terpelihara dengan kesadaran dan keyakinan hukum masyarakat secara romantic dan bersahaja. Adat orang Indonesia itu sendiri merupakan pencerminan dan penjelmaan daripada kepribadian dan jiwa bangsa Indonesia dari abad keabad. Keradaaan adat Indonesia juga bermuara pada filosofi "Bhineka Tunggal Ika"6

Menurut Koetjaraningrat dalam Nyoman Serikat, berbicara mengenai hukum adat maupun hukum pidana adat tidak bisa lepas dari pembicaraan aspek kebudayaan bangsa Indonesia. Oleh karena hukum dan juga hukum pidana dan merupakan perwujudan dari kebudayaan bangsa Indonesia. Pada hakikatnya kebudayaan itu mempunyai tiga perwujudan yaitu, pertama, wujud kebudayaan sebagai suatu kompleks dari ide-ide, gagasan serta nilai-nilai, kaidah-kaidah dan sebagainya, kedua, kebudayaan dapat mewujudkan diri sebagai suatu kompleks aktivitas kelakuan berpola dari manusia dalam masyarakat, ketiga, kebudayaan dapat berwujud sebagai benda-benda hasil karya manusia $^{7}$.

\footnotetext{
${ }^{6}$ Muhamad Erwin (2016). Filsafat Hukum Refleksi Kritis Terhadap Hukum dan Hukum Indonesia (dalam Dimensi Ide dan Aplikasi). cetakan kelima, Jakarta: RajaGrafindo Persada. p. 398.

${ }^{7}$ Nyoman Serikat Putra Jaya, op, cit, hlm 31.
} 
Lebih jauh menurut Hermin, sistem nilai-nilai budaya bangsa dengan demikian terdiri dari konsep-konsep yang ada dalam alam pikiran sebagian besar warga masyarakat yang merupakan warga dari kebudayaan yang bersangkutan, yaitu mengenai hal-hal yang harus mereka anggap penting dan bernilai dalam hidup, karena itu sistem nilai budaya biasanya berfungsi sebagai pedoman untuk berbuat. Yang penting yaitu sebagai suatu sistem yang mengontrol agar perbuatan-perbuatan manusia dalam masyarakat. Di dalam mengontrol ini masyarakat mempunyai suatu pola untuk mengukur apakah sesuatu perbuatan itu baik atau buruk, diperbolehkan atau tidak oleh masyarakat di mana pelaku perbuatan tadi hidup dan menjadi anggota ${ }^{8}$.

Hukum atau norma hukum sebagai pedoman bagi manusia untuk berbuat atau tidak berbuat mempunyai akibat hukum apabila normanya tidak ditaati atau dilanggar. Tiaptiap bangsa mempunyai hukumnya sendiri dan sebagaimana halnya dengan bahasa, maka hukumpun hidup dan diciptakan masyarakat karena hukum merupakan kehidupan dari bangsa itu sendiri. ${ }^{9}$ Norma hukum tersebut harus nyata, tumbuh dari suatu kehidupan dan berasal dari bangsa tersebut sehingga menjiwai dan mudah untuk dipahami dalam beraktivitas.

Seperti yang dikatakan oleh Savigny, di bawah term volkgeist, menurut Savigny terdapat hubungan yang organik antara hukum dengan watak atau karakter suatu bangsa. Hukum hanyalah cerminan dari volkgeist. Oleh karena itu hukum adat tumbuh dan berkembang dalam Rahim volgeist, harus dipandang sebagai hukum kehidupan yang sejati. Hukum sejati itu tidak dibuat, ia harus ditemukan. Legislasi hanya penting selama ia memiliki sifat deklaratif terhadap hukum sejati itu. Begitu pula persoalan utama dalam pengelolaan hukum, bukan hanya membentuk asas dan doktrin secara artifisial. Tapi menemukan asas dan doktrin dalam nilai-nilai hukum yang hidup ${ }^{10}$.

Hukum Adat, menurut pandangan Soepomo diartikan sebagai "suatu hukum yang hidup, karena ia menjelmakan perasaan hukum yang nyata dari rakyat, serta hukum adat bersifat dinamis dan akan tumbuh serta berkembang sejalan dengan perkembangan masyarakatnya." Temuan Soepomo tersebut bertitik tolak dari konsepsi pemikiran Friedrich Carl von Savigny dengan madzab sejarah dan kebudayaannya dari van Vollenhoven. Oleh sebab itu maka hukum adat bersifat dinamis dan akan tumbuh serta berkembang sejalan dengan perkembangan masyarakatnya. Dalam bahasa Friedrich Carl von Savigny, hal tersebut disebut Volksgeist (jiwa bangsa). Volksgeist berbedabeda menurut tempat dan zaman yang dinyatakan dalam bahasa adat-istiadat dan organisasi sosial rakyat. Hampir identik dengan pendapat tersebut maka penggagas sosiologi hukum (sosiology of law) Eugene Ehrlich mengatakan bahwa, "The centre of gravity of legal development lies not ini legislation nor in juristic science, nor in judicial decision, but in society it self". Eugene Ehrlich mengganti term voksgeist Savigny dengan term yang khusus dan lebih rasional yaitu fakta-fakta hukum (Rechtstaatsachen /fact of law) dan hukum yang hidup di dalam masyaraat (living law of the people). ${ }^{11}$

\footnotetext{
${ }^{8}$ Ibid, hlm 32.

${ }^{9}$ Ibid

${ }^{10}$ Bernad L Tanya dkk (2013). Teori Hukum Strategi Tertib Manusia Lintas Ruang dan Generasi. Yogyakarta: Genta Publishing, hlm 94

${ }^{11}$ Lilik Mulyadi, op, cit. hlm 231.
} 
Sehingga menurut Soejono Soekanto, pada dasarnya, hukum adat tidak saja merupakan adat-adat yang mempunyai akibat-akibat hukum, atau keputusan-keputusan yang berwibawa dari kepala-kepala rakyat, karena antara adat yang mempunyai akibat hukum dan yang tidak mempunyai akibat hukum tidak ada pemisahan yang tegas. Dengan kata lain bahwa setiap kebiasaan yang kemudian menjadi perilaku sehari-hari merupakan hukum adat ${ }^{12}$

Polarisasi hukum adat tersebut tidak membedakan antara hukum pidana adat, hukum perdata adat, hukum tata negara adat dan lain sebagainya. Konsekuensi logisnya bahwa hukum adat tidak mengenal pemisahan secara tegas antara hukum pidana dengan hukum perdata (privat) dan diantara keduanya saling berkorelasi satu sama lain. Sehubungan dengan hal tersebut, tidak ada perbedaan prinsip dalam prosedur penyelesaian perkara-perkara pelanggaran hukum adat. Jika terjadi pelanggaran para fungsionaris hukum (penguasa/kepala adat) berwenang mengambil tindakan konkret, baik atas inisiatif sendiri atau berdasarkan pengaduan pihak yang dirugikan ${ }^{13}$.

Karena tidak ada pembedaan secara jelas maka para sarjana hukum menggunakan istilah yang berbeda-beda untuk menyebut bidang hukum terutama hukum pidana adat. Ter Haar menggunakan terminologi delik adat, Soerjono Soekanto menyebutnya sebagai hukum penyelewengan adat. I Gede $\mathrm{AB}$ Wiranata menggunakan istilah hukum pelanggaran adat yang berasal dari istilah Belanda yaitu adat delicten recht ${ }^{14}$, Van Vollen Hoven pun menyebut dengan delik adat ${ }^{15}$.

Munculnya beragam istilah yang merujuk pada hukum pidana barat tersebut disebabkan karena memang pada dasarnya istilah hukum pidana tidak dikenal dalam hukum adat yang tidak memisahkan dengan tegas antara hukum privat dengan hukum publik. Oleh karena para ahli hukum terlebih dulu mengenal hukum Eropa dan Barat yang mengenal istilah hukum pidana (publik) dan hukum privat (perdata), maka frame yang dipakai dalam menelaah hukum adatpun cenderung menggunkan frame yang sama pada telaah hukum Eropa dan barat ${ }^{16}$

Hukum pidana adat salah satu dari living law yaitu hukum yang hidup dan akan terus hidup selama ada manusia budaya, ia tidak akan dapat dihapus dengan perundangundangan. Andaikata diadakan juga undang-undang yang menghapuskannya akan percuma saja, malahan hukum pidana perundang-undangan akan kehilangan sumber kekayananya. Oleh karena hukum pidana adat itu lebih dekat hubungannya dengan antropologi hukum dan sosiologi dari pada hukum perundang-undangan ${ }^{17}$.

Hukum pidana adat menunjukkan peristiwa dan perbuatan yang harus diselesaikan (dihukum) karena peristiwa dan perbuatan itu telah menggangu keseimbangan masyarakat. Hukum pidana barat menitik beratkan pada adanya "sebab" sehingga seseorang dapat diancam dengan hukuman, maka hukum pidana adat menitik beratkan pada adanya akibat. Walaupun sedangkan yang merupakan peristiwa itu tidak ada ketentuan atau larangannya, apabila akibatnya membawa kerugian dan bertentangan

\footnotetext{
${ }^{12}$ Ibid

${ }^{13}$ Ibid, hlm 232

${ }^{14}$ Ferry Fathurokhman, (2016). Hukum Pidana Adat Baduy dan Pembaharuan Hukum Pidana. Depok: INCA Publishing. hlm 52.

${ }^{15}$ Hilman Hadi Kusuma (1984). Hukum Pidana Adat, cetakan kedua, Bandung: Alumni hlm 19.

${ }^{16}$ Ferry Fathurokhman, op, cit, hlm 52.

${ }^{17}$ Hilman Hadikusuma, Hukum Pidana... op, cit, hlm 20.
} 
dengan pihak yang terkena akibat itu maka pihak yang menyebabkan akibat itu harus bertanggung jawab atas perbuatannya. ${ }^{18}$ Timbulnya reaksi masyarakat bertujuan untuk mewujudkan keseimbangan masyarakat kembali. Tetapi oleh karena reaksi masyarakat diberbagai lingkungan masyarakat adat itu berbeda-beda maka hukum pidana adat diseluruh Indonesia tidak sama ${ }^{19}$.

Menurut Anto Soemarman, Beberapa sarjana kemudian memberikan pengertian mengenai hukum pidana adat untuk dapat memberikan pemahaman lebih lanjut yang tentunya berpijak pada karakteristik hukum pidana adat pada umumnya. Van Vollen Hoven mengartikan delik adat sebagai perbuatan yang tidak diperbolehkan. Konsep delik adat Van Vollen Hoven yang menjadi inti delik dari delik adat adalah perbuatan yang dilarang dan sanksi sebagai akibat hukumnya tersebut dalam hukum pidana identik dengan perbuatan pidana/tindak pidana. ${ }^{20}$

Menurut Ter Haar, untuk dapat disebut tindak pidana adat, perbuatan itu harus mengakibatkan kegoncangan dalam neraca keseimbangan masyarakat. Kegoncangan itu tidak hanya terdapat apabila peraturan hukum dalam suatu masyarakat dilanggar, tetapi juga apabila norma-norma kesusilaan, keagamaan dan sopan santun dalam masyarakat dilanggar $^{21}$. Soerojo Wignjodipoero mengutif pendapat Lesquiliier, pada dasarnya suatu delik adat itu merupakan suatu tindakan yang melanggar perasaankeadilan dan kepatutan yang hidup dalam masyarakat, sehingga menyebabkan terganggunya ketentraman serta keseimbangan masyarakat yang bersangkutan guna memulihkan kembali ketentraman dan keseimbangan itu, maka terjadi reaksi-reaksi adat. Dan reaksirekasi adat ini merupakan tindakan yang bermaksud mengembalikan ketentraman magis yang diganggu dan meniadakan atau menetralisasikan suatu keadaan sial yang ditimbulkan oleh suatu pelanggaran adat.

Nyoman Sarikat Putra Jaya, Bahwa tindak pidana adat merupakan tindakan yang melanggar perasaan keadilan dan kepatuhan yang hidup dalam masyarakat, sehingga menyebabkan terganggunya ketentraman serta keseimbangan masyarakat yang bersangkutan. Guna memulihkan kembali ketentraman dan keseimbangan itu, maka terjadi reaksi-reaksi adat. Dan reaksi-reaksi adat ini merupakan tindakan yang bermaksud mengembalikan ketentraman magis yang diganggu dan meniadakan atau menetralisasikan suatu keadaan sial yang ditimbulkan oleh suatu pelanggaran adat."22

Ayah Mursyid ${ }^{23}$ pun memberikan definisi tentang hukum pidana adat adalah perbuatanperbuatan yang melanggar larangan-larangan adat yang mengakibatkan kerugian tidak hanya bagi korban tetapi juga bagi lingkungan dan alam, maka harus dilakukan pembersihan (bobokoran) dengan upacara adat untuk menghindari musibah dan mengembalikan suasana alam seperti semula ${ }^{24}$

Menurut Soerojo Wignjodipuro dalam bidang-bidang hukum adat, hukum pidana adat salah satu bidang hukum adat yang terdesak ${ }^{25}$ maka dalam rangka pembangunan hukum

\footnotetext{
${ }^{18} \mathrm{Ibid}, \mathrm{h} \operatorname{lm} 18$.

${ }^{19} \mathrm{Ibid}$, hlm 20.

${ }^{20}$ Ferry Fathurokhman, op, cit, hlm 53.

${ }^{21}$ Nyoma Sarikat Putra Jaya, op, cit, hlm 33.

22 ibid, p. 34.

${ }^{23}$ Ayah Mursyid adalah salah satu tokoh masyarakat Adat Baduy yang saat ini memegang amanah sebagai wakil jaro kampung Cibeo

${ }^{24}$ Wawancara dengan Ayah Mursyid di Kampung Cibeo tanggal 28 agustus 2019 jam 19.00 WIB

${ }^{25}$ Ibid, hlm 18.
} 
nasional termasuk juga KUHP menurut Menurut I Gusti Nyoman Sidiarsa, hukum yang yang akan dibuat harus berdasarkan Pancasila dan juga berkepribadian Indonesia. Hukum adat termasuk juga hukum pidana adat mau tidak mau harus dapat tempat dalam hukum nasional $^{26}$. Sanksi adat atau reaksi adat sebagai reaksi yang harus dikenakan terhadap pelanggar tindak pidana adat.

Dicantumkannya ketentuan Pasal 1 ayat 3 RUU KUHP tahun 2019, berarti rancangan KUHP menganut ajaran sifat melawan hukum materil, baik dalam fungsinya yang positif maupun negatif. Ajaran sifat melawan hukum formil menentukan suatu perbuatan itu melawan hukum apabila bertentangan dengan hukum tertulis atau undangundang. Ajaran sifat melawan hukum materil menentukan suatu perbuatan melawan hukum tidak hanya bertentangan dengan hukum tertulis tetapi juga bertentangan dengan asas-asas hukum yang hidup di dalam masyarakat. Hukum pidana adat dapat menjadi:

a. Sumber hukum yang positif dalam arti hukum pidana adat menjadi dasar hukum pemeriksaan perkara di pengadilan negeri

b. Sumber hukum yang negatif dalam arti ketentuan-ketentuan hukum (pidana) adat dapat menjadi alasan pembenar, alasan memperingan pidana atau mempeberat pidana. $^{27}$

Dicantumkannnya sanksi berupa pemenuhan kewajiban adat dalam RUU KUHP meskipun sifatnya hanya sebagai pidana tambahan maka bagi hakim yang bertugas tidak meragukan lagi untuk menjatuhkan sanksi adat. Pada dasarnya, pidana tambahan dapat dijatuhkan bersama-sama dengan pidana pokok, sebagai pidana yang berdiri sendiri atau dapat dijatuhkan bersama-sama dengan pidana tambahan yang lain. Konsepsi pidana tambahan berupa pemenuhan kewajiban adat setempat atau kewajiban menurut hukum yang hidup dalam masyarakat atau pencabutan hak yang diperoleh korporasi dapat dijatuhkan walaupun tidak tercantum dalam perumusan tindak pidana. Eksistensi adanya penjatuhan pidana tambahan dimaksudkan untuk menambah pidana pokok yang dijatuhkan dan pada dasarnya bersifat fakultatif. Begitu pula yang dikatakan Barda Nawawi $^{28}$ pemenuhan kewajiban adat setempat atau kewajiban menurut hukum yang hidup dalam masyarakat di dalam konsep RUU KUHP merupakan salah satu aspek perlindungan terhadap korban dimana jenis pidana ini pada dasarnya dapat juga dilihat sebagai bentuk pemberian ganti rugi kepada korban. Hanya saja yang menjadi korban di sini adalah masyarakat adat.

Disamping Pancasila sebagai ide yang perlu diwujudkan dalam hukum pidana nasional. Pancasila juga berfungsi sebagai pembatas atau alat pengukur, apakah nilai-nilai yang ada dalam masyarakat masih dapat dipertahankan lebih untuk dijadikan bahan dalam pembentukan KUHP Nasional.

Tindak pidana itu tumbuh, berkembang dan hilang sesuai dengan perkembangan masyarakat itu sendiri. Perubahan nilai-nilai secara cepatada kemungkinan juga disertai perihal nilai-nilai tradisional yang ada dalam masyarakat Indonesia yang terdiri dari berbagai adat istiadat dan kebiasaan. Oleh karena itu pengungkapan hukum adat secara mendasar akan bermanfaat dalam rangka pembuatan KUHP nasional. Karenanya disadari pula bahwa kendala yang dihadapi oleh hukum pidana adat menjadi berlaku

\footnotetext{
${ }^{26}$ Nyoman Sarikat Putra Jaya, op, cit, hlm 277.

${ }^{27}$ Ibid

${ }^{28}$ Barda Nawawi Arief (2001), Masalah Penegakan Hukum \& Kebijakan Penanggulangan Kejahatan, Bandung: PT Citra Aditya Bakti, hlm 59.
} 
secara nasional adalah bahwa hukm pidana adat itu hanya berlaku untuk daerah-daerah tertentu saja. Secara a contrario dapat dikatakan bahwa proses unifikasi secara substantif masih perlu diperjuangkan mengingat kebhinekaan pidana adat yang ada di Indonesia. ${ }^{29}$

Von Savigny yang dikenal dengan mahzab hukum sejarah, bahwa hukum ialah pernyataan dari jiwa bangsa dan semboyannya adalah "das recht wird nichr memacht, es ist und wird mit dem voike" yang berarti hukum itu tidak di buat, tetapi berada dan berkembang dengan jiwa bangsa. Hal serupa didukung oleh Eugen Ehrlich yang membedakan antara positive law dan living law dengan mengemukakan bahwa;

The positif law can be effective only when the it corresponden to the living law; that is, when legal codes are based on underlying social norm or real life in other words law is to be understood as part of the social order. ${ }^{30}$

Hukum pidana adat sesungguhnya tidak bertumpu pada cara pandang positivistik yang mengidentivikasikan bahwa hukum adalah undang-undang dengan kata lain hukum pidana adat adalah hukum yang menggambarkan suatu perbuatan dan peristiwa yang berakibat hukum maka perbuatan dan peristiwa tersebut harus diselesaikan (dihukum) dikarenakan telah mengganggu keseimbangan masyarakat.

Perspektif hukum pidana adat, hukum adat diabaikan dan ada di pinggiran. Alasannya adalah bahwa prinsip legalitas untuk memberlakukannya tidak ada. Kajian terhadap hukum pidana adat secara secara akademik juga dilupakan apalagi oleh pembuat kebijakan, dibeberapa negara bahkan hukum pidana adat merupakan kajian yang tidak terlalu relevan terhadap keputusan pengadilan, secara emirik hukum pidana adat bisa berguna sebagai sarana investigasi bagi hukum-hukum local terhadap praktek hukum tindak pidana adat, yang mungkin menandakan semacam perbedaan dan paradoks.

"In the perspective of traditional criminal law, customary law is ignored and exists in the margins. The reason is that the principle of legality requires the exclusion of customary law. The real status and function of customary law in judicial practice attracts no attention in academic circles, and is outside the views of lawmakers. However, in whatever country, customary law's status in theory and in legislation is not necessarily equivalent to its real status in judicial practice, which possibly signifies some kind of discrepancy and paradox, 31

Dikatakan oleh Marc Ancel, bahwa setiap masyarakat yang terlembaga dan terstruktur secara terorganisir mempunyai sistem hukum salah satunya hukum pidana yang terdiri dari prosedur hukum pidana, mekanisme pelaksanaan hukum pidana dan peraturanperaturan hukum pidana disertai dengan sanksinya ${ }^{32}$. Begitu pula masyarakat hukum adat Baduy mempunyai peraturan hukum dan sanksi yang mengikat dan lembaga adat yang tersetruktur. Beberapa peraturan hukum atau larangan ${ }^{33}$ yang dipegang teguh oleh masyarakat Baduy yang dikatakan Ayah Mursyid yaitu:

${ }^{29}$ Ibid

${ }^{30}$ Ibid, hlm 278.

${ }^{31} \mathrm{Du}$ Yu, Customary Law in the Practice of Criminal Law: A Real and Powerpul Role, Peking University Law Journal, vol 1 2013, hlm 1

${ }^{32}$ Barda Nawawi Arief, loc, cit, hlm 55.

${ }^{33}$ Larangan istilah yang sering dikatakan oleh masyarakat hukum adat Baduy untuk menyatakan peraturan yang memuat tentang perbuatan-perbuatan yang tidak boleh dilakukan 
1. Dilarang membunuh orang;

2. Dilarang memarahi orang lain;

3. Dilarang menikah lebih dari satu orang;

4. Dilarang makan diwaktu malam;

5. Dilarang minum yang memabukan;

6. Dilarang berduaan berlainan lawan jenis;

7. Dilarang berzina;

8. Dilarang mencuri;

9. Dilarang berbohong;

10. Dilarang melanggar adat;

11. Dilarang meminta-minta atau mengemis;

12. Dilarang menyiksa binatang ${ }^{34}$.

Pernyataan Ayah Mursyid ini dilengkapi oleh Jaro Saija ${ }^{35}$ bahwa peraturan hukum pidana di Baduy pada dasarnya masih campuran antara pidana berat dan pidana ringan, pidana berat yaitu membunuh, berzina, mabuk, mencuri terutama mencuri padi, mencuri kayu di hutan larangan, sedangkan yang lainnya adalah tindak pidana yang dikategorikan ringan.

Peraturan hukum adat banyak kelemahannnya karena sifat dasar dari hukum adat yang tidak tertulis sehingga besar kemungkinan ada suatu ketidak seragaman antara para peneliti yang melakukan penelitian tentang hukum pidana adat Baduy, terlebih yang melakukan penelitian tentang hukum pidana adat masyarakat Baduy masih sangat jarang, para peneliti lebih banyak melakukan penelitian di masyarakat Baduy tentang tanah ulayat, kearifan lokal, budaya, sistem pertanian, sedangkan hukum pidana hanya dijadikan sebagai tambahan yang menunjukkan adanya hukum pidana di masyarakat hukum adat Baduy.

Masyarakat hukum adat Baduy memandang bahwa manusia dan alam semesta merupakan kesatuan yang tak terpisahkan satu dengan yang lainnya, terkemas dalam kontruksi berpikir yang berwawasan kosmologis. Oleh karena itu untuk mencapai kebahagiaan dan keseimbangan alam, maka segala tingkah laku harus memperhitungkan kekuatan gaib yang tidak tampak dan menyesuaikan diri dengan tata cara sebagaimana yang telah ditetapkan. Setiap pelanggaran hukum adat atau tindak pidana adat akan berakibat kerusakan, tidak hanya pada tataran badan dan nyawa manusia (korban), melainkan juga menimbulkan gangguan atau kegoncangan dalam alam magis akibat terjadi ketidakseimbangan alam. Hal ini membawa konsekuensi, penyelesaian pelanggaran hukum tidak cukup hanya berupa penyelesaian secara lahiriah melainkan juga harus meliputi pemulihan keseimbangan alam.

Untuk mengatasi permasalahan tersebut antara hukum adat yang hidup dan berkembang dimasyarakat dengan hukum nasional atau hukum positif dapat dilakukan beberapa cara

\footnotetext{
${ }^{34}$ Wawancara dengan Jaro Saija di Kampung Cibeo tanggal 21 September 2019 jam 19..00 WIB

${ }^{35}$ Wawancara dengan Jaro Saija di Kampung Cibeo tanggal 22 September 2019 jam 11.00 WIB
} 
yaitu:

a. Menerapkan pluraslime hukum. Sebagai Negara pluralisme, seharusnya Indonesia tidak kesulitan menerapkan pluralisme hukum dalam produk perundangperundangannya, karena pluralisme hukum bukan merupakan barang yang asing bagi masyarakat Indonesia. Penyatuan antara religius law, folk law dan hukum nasional menjadi satu akan lebih baik dan lebih teruji karena hukum nasional berasal dari volgeist atau jiwa bangsa.

b. Dengan cara penemuan hukum. Meskipun nilai hukum yang hidup tidak selalu seirama dengan hukum nasional, namun hakim bisa mengambil nilai-nilai yang berlaku dalam hukum adat sebagai pijakan dalam mengambil putusan. Secara normatif penemuan hukum diatur berdasarkan Undang-Undang Nomor 48 tahun 2009 tentang Kekuasaan Kehakiman, Pasal 5 ayat 1 "hakim dan hakim konstitusi wajib menggali, mengikuti dan memahami nilai-nilai hukum dan rasa keadilan yang hidup dalam masyarakat".

Dalam penemuan hukum. Hukum tertulis bukan merupakan satu-satunya hukum yang berlaku. Maka hakim harus melakukan upaya untuk meneliti nilai-nilai yang hidup di masyarakat, hakim bisa melakukannya dengan memanggil dan mendengarkan keterangan ahli dalam proses persidangan. Tujuan ini dimaksudkan agar putusan hakim sesuai dengan hukum dan rasa keadilan di masyarakat.

c. Pembentukan hukum. Pembentukan hukum memang secara ideal disusun secara prosedural, namun yang menjadi titik sentral dalam penemuan hukum seharusnya adalah substansi hukum dengan bersandarkan pada nilai-nilai kearifan lokal yang terumuskan dalam hukum adat. Dengan kata lain yaitu memformilkan perbuatan-perbuatan tercela yang menurut pandangan masyarakat hukum adat sebagai perbuatan yang merugikan dan merusak keseimbangan alam.

Secara prinsip, penerapan hukum pidana adat mempunyai keunggulan yaitu:

a. Prinsip Kearifan Lokal

Merupakan prinsip yang melandaskan penyelenggaraannya atas dasar tradisi yang telah dipertahankan dan dapat diterima luas di tengah masyarakat adat itu, secara turun temurun. Kearifan lokal dikenali sebagai bagian kehidupan masyarakat yang sangat penting sebagai landasan interaksi sosial sekaligus penanda moralitas yang diakui sebagai keyakinan setempat.

\section{b. Prinsip Keadilan Sosial}

Prinsip yang mengedepankan terwujudnya rasa keadilan yang dirasakan sangat penting di tengah masyarakat keberlakuannya, atau suatu yang memiliki kebermaknaan sosial (social significance).

c. Prinsip Hak Asasi Manusia

Prinsip ini meliputi cara pandang universalitas hak asasi manusia, non- diskriminasi, kesetaraan, pemartabatan manusia, tidak memisahkan hak asasi yang satu dengan 
hak asasi lainnya, serta menempatkan tanggung jawab negara dalam upaya memajukan dan melindungi hak asasi manusia ${ }^{36}$.

Prinsip-prinsip di atas, ada dalam masyarakat adat Baduy dalam penyelesaian perkara, masyarakat adat Baduy dapat dikategorikan dalam subjek parokial, karena dalam penyelesaian perkara lebih mengutamakan penggunaan hukum adatnya dan secara institusi penyelesaiannya pun bersifat tradisional dan itu dinilai lebih memberikan kedamaian dan keadilan dibandingkan dengan penggunaan hukum yang lain.

\section{KESIMPULAN}

Dalam perkembangan hukum saat ini, Indonesia sedang melakukan pembangunan hukum diantaranya adalah hukum pidana nasional. Pembangunan hukum pidana nasional harus mengandung nilai-nilai yang terkandung dalam hukum adat sebagai jiwa bangsa yang menjadi dasar hukum pidana nasional, salah satu hukum adat yang bisa diambil nilai-nilainya adalah hukum pidana adat Baduy yang sampai saat ini masih eksis dan dilaksanakan secara murni sampai dengan saat ini. walaupun ada perbendaan namum bisa dilakukan harmonisasi antara hukum adat dengan hukum nasional sehingga bisa menyempurnakan hukum pidana nasional yang datang.

\section{Daftar Pustaka}

Barda Nawawi Arief (2001), Masalah Penegakan Hukum \& Kebijakan Penanggulangan Kejahatan, Bandung: PT Citra Aditya Bakti

C. Dewi Wulansari (2014). Hukum Adat Indonesia Suatu Pengantar. Jakarta: Refika Aditama

$\mathrm{Du} \mathrm{Yu}$, (2013). "Customary Law in the Practice of Criminal Law: A Real and Powerpul Role". Peking University Law Journal, vol 1

Ferry Fathurokhman. (2016). Hukum Pidana Adat Baduy dan Pembaharuan Hukum Pidana. Depok: INCA Publishing

Hilman Hadi Kusuma (1984). Hukum Pidana Adat, cetakan kedua, Bandung: Alumni

Lilik Mulyadi (2013). "Eksistensi Hukum Pidana Adat Di Indonesia: Pengkajian Asas,

Norma, Teori, Praktik dan Prosedurnya”. Jurnal Hukum dan Peradilan Volume 2 Nomor Juli 2013

L Tanya dkk (2013). Teori Hukum Strategi Tertib Manusia Lintas Ruang dan Generasi. Yogyakarta: Genta Publishing.

Muhamad Erwin (2016). Filsafat Hukum Refleksi Kritis Terhadap Hukum dan Hukum Indonesia (dalam Dimensi Ide dan Aplikasi) cetakan kelima, RajaGrafindo Persada, Jakarta

Nyoman Serikat Putra Jaya (2016). "Hukum (Sanksi) Pidana Adat Dalam Pembaharuan Hukum Pidana Nasional", Jurnal Masalah-Masalah Hukum, Jilid 45 No. 2

Soerojo Wignjodipoero (2017). Pengantar dan Asass Asas Hukum Adat, cetakan kedelapan, Jakarta: Gunung Agung.

\footnotetext{
${ }^{36}$ Badan Pembinaan Hukum Nasional Kementerian Hukum Dan Hak Asasi Manusia RI, hlm 9.
} 